\title{
VI. 今後の展開
}

福島特別プロジェクト代表 田中 知

事故から約 3 年が経過したが，除染，復旧復興は遅れ ている。同じ日本の一部がそのような状況であることを 大変残念に思う。また，事故を起こした原子力関係の学 会に所属するものとして, 責任を更に強く感じている。 まさに「福島の復興なくして日本の本当の再生はない」と いうことに関して学会として行うべきことは多い。プロ ジェクト開始後約 2 年経過後の現在においてその念は一 段と高くなっている。これまでの反省も踏まえて，今 後，「福島特別プロジェクト」のなすべきことはますます 大きくなっている。

今後, 次のような点に留意して, それこそ学会の総力 を挙げて, 会員各位の援助を頂きながら活動を展開して いきたい。

(1) 有効な除染の加速

費用対効果が大きく，また早期あるいは将来の帰還に つながり，営農など産業復興につながる除染及び発生廃 棄物処理について学術的観点から提言を行うとともに住 民説明を行う。ここでは低レベル放射線影響についての 科学的な説明や，除染目標，個人線量管理方法の提言な ども含まれる。

(2) 環境動態についての学術的な評価

再污染に対して強い懸念を持っている住民が多い, 学 会会員, 研究機関等で行われている研究成果を除染効果 と結び付けて解説する。

(3) 福島県，地元市町村への支援

福島県や地元市町村との連携を更に強める。その中に は専門家の半駐在, 平成 27 年度に福島県が作る福島県 環境創造センター(仮称)への支援などが含まれる。
（4）除染情報プラザへの専門家としての支援

環境省, 福島県除染情報プラザは, 除染の加速のみで はなく, 今後は復興再生に関する情報発信拠点, 住民か らのワンストップコンタクト場所としてますます重要な 意味を持つ。このプラザへの支援をさらに良い仕組みを 考えつつ強化する。

(5) 復興, 再生プランへの学術的支援

事故後の復興, 再生は他に例を見ない大きなかつ歴史 的作業である。学会プロジェクトとしても, 外国での 例, 他災害からの再生例, 地域論などをもとに学術的な 観点から提案，支援する。

(6) 地元に密着したコミュニケーションの展開 シンポジウムやリスクコミュニケーションで行うべき 内容は時間の経過とともに変化している。今後必要なコ ミュニケーションについて常に関係者と相談しつつ, 有 効なコミュニケーションを実行する。

（7）より現場的対応を可能とする体制の強化

福島浜通り, 中通りに福島特別プロジェクト事務所を 開設することにより即時, 現場的対応が可能になるよう な方策を検討したい。

（8）福島第一原子力発電所廃炉進展との関倸強化

污染水問題, 環境一の放出, 放射性廃棄物処理処分な ど, 周辺市町村の方々は廃炉作業の進展に強い関心があ るとともに，環境への放射性物質放出が問題とならない 程度に制御されているかに強い関心がある。これらにつ いて学会内の専門委員会や事故調査委員会, 㧤よびその 後身の委員会等と協力しながら地元住民に対して丁寧な 説明を行う。同時に必要に応じて, 国, 東京電力に対し て廃炉作業に関しての提言を行う。 